\title{
APUNTES PARA UNA HISTORIA DE LOS HIMNOS QUECHUAS DEL CUSCO
}

\section{NOTES ON THE HISTORY OF THE QUECHUA HYMNS OF CUZCO}

\author{
Alan Durston ${ }^{1}$
}

\begin{abstract}
La interpretación de himnos en quechua es una de las más arraigadas expresiones del cristianismo andino. Este artículo intenta una primera aproximación a los textos de los himnos quechuas que se cantan actualmente en la ciudad del Cusco en cuanto a sus orígenes históricos, y propone una cronología de la evolución del género del siglo XVI al XX. Se sugiere que la mayoría de los himnos vigentes corresponden a un tipo que se desarrolló hacia fines del período Colonial y que no aparece con claridad en el registro escrito hasta mediados del siglo XIX.
\end{abstract}

Palabras claves: himnos, literatura quechua, religiosidad andina, Cusco.

The performance of hymns in Quechua is one of the most deeply-rooted expressions of Andean Christianity. This article attempts a preliminary analysis of the texts of the Quechua hymns that are currently sung in the city of Cuzco with regard to their historical origins, and proposes a chronology of the development of the genre from the sixteenth to the twentieth century. It is suggested that most current hymns belong to a type that developed towards the end of the Colonial Period and does not appear clearly in the written record until the mid-nineteenth century.

Key words: Hymns, Quechua literature, Andean religiosity, Cuzco.

Un artículo sobre himnos cristianos en quechua ${ }^{1}$ podrá parecer un poco fuera de lugar en un número especial de Chungara dedicado a John Murra. El gran estudioso de las formaciones socioeconómicas andinas rara vez menciona al quechua en sus obras más conocidas. Sin embargo, Murra tomó muy en serio el estudio de ese idioma. Mientras que los resultados de sus propios esfuerzos no estuvieron a la altura de sus expectativas (Murra emprendió el aprendizaje del quechua a una edad ya madura), insistió en que sus alumnos avanzaran más allá e hizo de Cornell la primera universidad en EEUU donde se enseñó el quechua de forma regular ${ }^{2}$. El interés de Murra por el quechua puede atribuirse a las experiencias políglotas de su infancia y juventud, pero también fue reflejo de una estrecha amistad con José María Arguedas, el novelista, poeta y antropólogo quechua-hablante. Por ejemplo, la introducción escrita por Murra para la traducción inglesa de Los Ríos Profundos, obra novelística cumbre de Arguedas, enfatiza la fuerte presencia del quechua en la novela, recalcando lo difícil y a la vez productivo que fue para Arguedas tener que debatirse entre sus dos idiomas maternos (Murra 1978:x).
En su extenso artículo "Los himnos quechuas católicos cuzqueños", publicado en 1955 en la revista Folklore Americano, Arguedas resaltó la importancia del género, notando que la interpretación de himnos quechuas era muy difundida en la sierra peruana (como lo sigue siendo hoy, más de 50 años más tarde), y alegando incluso que "los himnos... constituyeron la principal y la más copiosa producción literaria en el idioma inca, desde la conquista" (Arguedas 1955:162). El estudio se basó en dos colecciones provenientes de la ciudad del Cusco y zonas aledañas: un himnario de 1912 proporcionado por José María Benigno Farfán, y una recopilación hecha por el sacerdote quechuista Jorge A. Lira. Los himnos dedicados a Dios y a Jesucristo fueron publicados junto con el artículo, con la intención de entregar los himnos a María y al Niño Jesús en un número venidero de Folklore Americano, cosa que al parecer nunca ocurrió.

Arguedas concibió el artículo como un primer ensayo que debía inspirar investigaciones futuras sobre las dimensiones filológicas y musicológicas del tema. Emprendió el estudio de la himnología quechua en una época cuando la historia del quechua y de la literatura quechua eran poco conocidas, y él

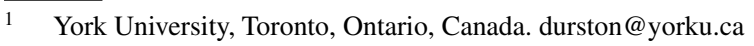


mismo resaltó la necesidad de trabajar con antecedentes más claros que los que él poseía (Arguedas 1955:136). Le interesó en particular la cuestión de los orígenes históricos de los himnos contenidos en las dos colecciones, preguntas relacionadas con el grado de continuidad con textos y géneros prehispánicos, y con la identidad de los autores (si eran sacerdotes quechua-hablantes o laicos indígenas o mestizos). Mientras que Lira afirmaba fehacientemente el origen incaico de muchos de los himnos, Arguedas se expresó sobre el tema con bastante más cautela, distinguiendo rasgos estilísticos, musicales e ideológicos que podrían o no reflejar una influencia incaica (Arguedas 1955:133-134, 151). Por otra parte, argumentó que algunos de los himnos utilizan expresiones similares al lenguaje de las canciones "profanas" o "folklóricas" del campesinado quechua-hablante, especulando que se había dado una influencia mutua entre el canto quechua sacro y el profano (Arguedas 1955:144-155).

A pesar del llamado de Arguedas se le ha dedicado muy poca atención al repertorio vigente de himnos quechuas. En los últimos años Enrique Pilco Paz ha estudiado a los intérpretes de himnos quechuas en el Cusco desde un punto de vista a la vez musicológico y social (Pilco Paz 2002, 2005). El presente artículo intenta una caracterización preliminar de los textos de los himnos quechuas vigentes hoy en día en la ciudad del Cusco y alrededores ${ }^{3}$, ubicándolos dentro de un panorama histórico del género. Propongo una tipología de himnos e intento establecer una relación entre cada tipo y un contexto histórico definido. La tipología que propongo es meramente un instrumento para intentar una interpretación histórica muy general de los himnos quechuas, y no debe tomarse como un esquema rígido y aplicable a todos los casos. Ya que carezco de los conocimientos técnicos para abordar las características musicales de los himnos, los he analizado principalmente como textos verbales. Sin embargo, no es posible obviar del todo la dimensión musical, y me he permitido algunas especulaciones basadas en los trabajos de Enrique Pilco Paz (2002, 2005) y Geoffrey Baker (2003).

\section{Los Himnos Quechuas en el Cusco Actual}

El contexto más frecuente del himno quechua es la misa. Aunque muy pocos sacerdotes dicen misa en quechua es común que se inserten himnos quechuas en los momentos claves. El Apu yaya Jesucristo, "himno oficial de la fe india" según Lira (Arguedas 1955:134), generalmente se canta como himno de entrada ${ }^{4}$. Otro himno muy difundido, el Apu Jesucristo, suele cantarse entre la epístola y el evangelio. La elevación de la hostia y el cáliz consagrados suele celebrarse con el Qanmi Dios kanki (también conocido como el Yuraq hostia santa), un himno eucarístico compuesto por el franciscano huamanguino Luis Jerónimo de Oré y publicado como parte del quinto cántico de su libro Symbolo Catholico Indiano (1598). Otros himnos eucarísticos en quechua, en especial el Mesan mast'asqa, se cantan al final de la misa mientras el pueblo comulga. También hay algunos textos propios de la misa que ocasionalmente se cantan en quechua, principalmente las Kiries, el Ofertorio y el Sanctus. Esta versión musicalizada de las plegarias de la misa (o quizá una versión en particular) es conocida como la "misa incaica", aunque los entendidos dicen que proviene de Bolivia (Ricardo Castro Pinto, comunicación personal, 2002). Hay bastante variabilidad con respecto a cuáles himnos se cantan en la misa y en qué momento, variabilidad que parece deberse a una falta de normativas provenientes de la jerarquía eclesiástica. Esta falta de normativas también explica, en parte, el hecho de que incluso aquellos sacerdotes que tienen un buen manejo del quechua se resistan a decir misa íntegramente en ese idioma. Si bien se han publicado varios devocionarios que contienen versiones quechuas de la misa, estos textos son el producto de esfuerzos individuales y además varían entre sí (p.ej., Andía 1950; Manya 1972; Porccheda Diana 1986; Quispe y García 1986; Vicente 1963).

La interpretación de himnos quechuas no se limita a la misa. Es obligatoria también en las procesiones y veladas de las fiestas patronales y de los santuarios. Hay un extenso repertorio de himnos marianos como el Qullanan María y el Virgen santa Diospa maman que se cantan en las fiestas de la Virgen. Las fiestas dedicadas a Cristo crucificado (Señor de Huanca, Señor de Coyllur Riti, y Señor de los Temblores) involucran la entonación de himnos como el Apu yaya Jesucristo y el himno de la pasión Jerusalen llaqta runa. Estos himnos pueden interpretarse en contextos que parecen ajenos a la liturgia católica tradicional. En la fiesta de Coyllur Riti, por ejemplo, los grupos de "ukukus" o "pabluchas" (especie de payasos sagrados) que suben al glaciar de Collque Puncu se detienen en 
pleno cerro a altas horas de la noche para cantar el Apu yaya Jesucristo y otros himnos a Cristo.

En otras palabras, existe un repertorio establecido de himnos quechuas, cada uno asociado con un contexto o uso litúrgico particular. Mientras que muchos de estos himnos son ampliamente conocidos, su interpretación en misas y veladas depende de conjuntos semi-profesionales. Estos conjuntos típicamente consisten en un músico que lidera la entonación de los himnos mientras toca un órgano (ya sea un órgano tubular, un armonio portátil (pampa piano) o, más frecuentemente, un órgano eléctrico), $\mathrm{y}$ un coro de mujeres que lo acompañan en el canto. Estos conjuntos son los herederos de una tradición que se remonta a los siglos XVI y XVII, cuando cada parroquia contaba con un maestro de capilla y un coro (Baker 2003). Algunos de los músicos trabajan de forma regular en una iglesia específica y se les puede considerar "maestros de capilla" dentro de la tradición colonial, pero muchos no tienen ese carácter institucional (Pilco Paz 2005). Los conjuntos suelen ser bastante móviles, siendo contratados para interpretar himnos quechuas en distintos lugares por los mayordomos de las fiestas locales, práctica que también se daba en la colonia (Baker 2003:198).

En cuanto a las vías de transmisión de los himnos, los especialistas usan cancioneros o himnarios impresos de data relativamente reciente como el Catecismo y Devocionario en Quechua del franciscano Norberto Andía (1950), que contiene más de 100 himnos. Los ejemplares o fotocopias de estos libros se han convertido en un recurso escaso y celosamente guardado por maestros y cantoras. Más preciados aún son los cancioneros manuscritos que algunos de los maestros más antiguos poseen (Pilco Paz 2005:192-195). Sin embargo, los libros por sí solos no aseguran la transmisión de un himno ya que por lo general no contienen la notación musical; la mayoría de los himnos registrados en publicaciones como la de Andía ya no se pueden cantar porque nadie conoce su "tono" o melodía 5 .

El uso del quechua en la liturgia y la paraliturgia católica es una práctica dinámica y heterogénea, no una reliquia del pasado. Atraviesa diferentes sectores sociales. Como advierte Pilco Paz (2002:4), hay una gran diferencia entre una velada en una fiesta parroquial y una misa en la catedral, por mucho que se canten los mismos himnos. En cualquier caso, el público son en su gran mayoría personas bilingües que exigen el uso del quechua en estos contextos litúrgicos a pesar de que entienden el castellano. Los motivos por este apego a los himnos quechuas son complejos y varían según el estrato social. Para muchos el quechua es el idioma "materno", el idioma de la intimidad y la familiaridad, y consecuentemente un himno quechua tiene una fuerte carga emocional. También se suele ver en el quechua un valor emblemático e identitario, una marca de "cusqueñidad" y de "tradición".

\section{Los Himnos en la Literatura Quechua Colonial}

Las primeras canciones quechuas de contenido cristiano parecen haber sido "taquíes" (de la palabra quechua taki, 'canto bailado') de estilo netamente andino. Hay varias referencias al uso de distintos géneros de taki, en particular harawis y hayllis, en fiestas y otros contextos litúrgicos durante el período 1550-1570. En las décadas de 1570 y 1580, período clave de reorganización colonial, hubo una reacción represiva contra los taquíes cristianizados, y en adelante predominaron los modelos europeos para el canto cristiano en quechua (Estenssoro Fuchs 1992, 2003:139-193 passim; cf. Durston 2007:146-154, 160-163). Los géneros de canto y poesía andinos al parecer habían carecido de una estructura estrófica (cf. Mannheim 1986), y por lo tanto los primeros himnos quechuas en sentido estricto habrían sido aquellos que siguieron modelos europeos.

El conjunto oficial de textos pastorales publicados en castellano, quechua y aymara por el Tercer Concilio Limense de 1582-1583 no incluye himnos ni habla del uso de la música en la evangelización (Tercer Concilio Limense 1985 [1584, 1585]). Sin embargo, no hubo que esperar mucho para que el franciscano Luis Jerónimo de Oré publicara su gran himnario quechua, el Symbolo Catholico Indiano (1598), que contiene los himnos cristianos en quechua más antiguos que se conocen (Oré 1992 [1598]). Estos son: una serie de siete "cánticos" (uno para cada día de la semana) narrando la creación, caída y redención que abarcan 165 páginas, un himno cosmogónico (El Capac eterno Dios) que se debía cantar durante la hora canónica de Completas, y un himno mariano. Después de Oré, el más importante compositor de himnos quechuas de la colonia fue el clérigo secular Juan Pérez Bocanegra, párroco de Belén en la ciudad del Cusco y después del pueblo de Andahuaylillas, quien en 1631 dio a la imprenta un manual sacramental que contiene tres 
himnos a María. Entre ellos se encuentra el Hanac pachap cussicuinin, que ha sido ampliamente interpretado y difundido en los últimos años debido al hecho de que Pérez Bocanegra incluyó la notación musical del himno en su manual (Pérez Bocanegra 1631:707-712). En 1641 el jesuita Pablo de Prado publicó su Directorio Espiritual, un devocionario quechua-castellano, que contiene un apéndice con letanías e himnos (Prado 1641). Estos himnos proceden del Symbolo Catholico Indiano con la excepción de una breve composición contemplando al Cristo crucificado.

Casi no hay himnos quechuas en la literatura pastoral publicada durante la segunda mitad del siglo XVII y el siglo XVIII, por lo general sumamente parca en comparación con el período anterior ${ }^{6}$. Hay, sin embargo, varios devocionarios manuscritos anónimos y sin fecha que circularon al margen del respaldo oficial requerido para la imprenta, algunos de los cuales contienen himnos (Rivet y Créqui-Montfort 1951-1956:I 200-221). De particular importancia es un devocionario proveniente de Ayacucho que por su escritura parece datar de fines del siglo XVIII ${ }^{7}$. Contiene versiones quechuas de himnos y salmos latinos, lo que representa una novedad ya que los himnos anteriores siempre eran composiciones nuevas y no traducciones de textos canónicos. El devocionario ayacuchano también contiene una Canción a Jesús Nazareno que se asemeja mucho a los himnos que comienzan a aparecer con frecuencia en la literatura pastoral a partir de la independencia, como se explicará en la siguiente sección.

Los himnos quechuas que datan de fines del siglo XVI y comienzos del XVII forman un conjunto claramente definido y relativamente bien documentado. Tanto los tipos de versificación como las melodías siguen cánones europeos. Los himnos de Oré imitaron de forma muy precisa algunos himnos latinos del breviario romano (Durston 2007:241242). Según Juan Carlos Estenssoro la melodía del Hanac pachap cussicuinin de Pérez Bocanegra corresponde al villancico, género religioso menos formal y solemne que los himnos de las horas canónicas (Estenssoro Fuchs 2003:303-304). Sin embargo, es importante recalcar que estas formas occidentales fueron combinadas con un lenguaje poético de origen andino, sobre todo a través del uso del paralelismo semántico-sintáctico y de imágenes asociadas a la cosmología y a las prácticas rituales andinas (Durston 2007 capítulos 7 y 8; Mannheim 1999).
¿Qué presencia tiene este "Tipo 1" del himno quechua en el repertorio cusqueño actual? Como ya se mencionó el Qanmi Dios kanki, himno eucarístico que suele interpretarse en las misas, es en realidad una versión ligeramente modificada de una parte del quinto cántico del Symbolo Catholico Indiano de Oré. Sin embargo, éste es el único caso claro de continuidad que he logrado identificar. La colección de himnos formada por Jorge A. Lira y publicada por Arguedas incluye un himno que Lira tituló Kkhapak wiñay Theos y que claramente corresponde al Capac eterno Dios de Oré, pero según el mismo Lira se trata de un himno "ya en desuso" (Arguedas 1955:132).

\section{El Siglo XIX}

Una de las consecuencias culturales más inmediatas del proceso de independencia fue la eliminación de las restricciones a la imprenta. Una imprenta se estableció por primera vez en Cusco durante las mismas guerras de la independencia, y a partir de 1828 comenzaron a publicarse localmente libros pastorales con textos quechuas. El primer libro importante del siglo XIX que contiene himnos nuevos se imprimió en Cusco con el título Tesoros Religiosos en Castellano y Qquichua y dataría de $1834^{8}$. Es de compilador anónimo y carece de cualquier explicación introductoria. Este libro consiste mayoritariamente de textos que no figuran en los impresos coloniales, entre ellos más de 30 himnos, muchos de los cuales se cantan actualmente. Nueve años más tarde, en 1843, apareció el Catecismo y Doctrina Cristiana en el Idioma Qquechua, editado por el franciscano Mariano Guzmán. El contenido de este libro coincide en gran medida con el de los Tesoros Religiosos, sólo que en una edición más cuidada y tipográficamente superior. De hecho, Guzmán acusó al editor anónimo de los Tesoros Religiosos de haber impreso el libro de forma desleal a partir de una versión manuscrita del Catecismo y Doctrina Cristiana que él le había prestado (Rivet y Créqui-Montfort 1951-1956:I 310).

En los Tesoros Religiosos y el devocionario de Mariano Guzmán encontramos un nuevo tipo de himno quechua que denominaré "Tipo 2". La característica más evidente de estos himnos en su dimensión verbal es la sencillez. Son esencialmente imploraciones íntimas y directas a Dios, Cristo o la Virgen con poco contenido doctrinal o narrativo. El hablante se presenta a sí mismo como un pecador 
indigno y humillado, culpable de los sufrimientos de Cristo y la Virgen. Típicamente estos himnos consisten en un número reducido de estrofas de cuatro versos relativamente cortos, a menudo octosílabos. Como ejemplo citaré la primera estrofa de un himno a María que aparece en los Tesoros Religiosos (Anónimo 1834:43) y que se canta actualmente con variaciones mínimas en las fiestas de la Virgen (p.ej., cuando se vela a la Virgen de Belén durante su estadía en el convento de Santa Clara para Corpus Christi):

\section{Virgen Santa Diospa maman \\ Virgen santa, madre de Dios}

\section{Huchasapacc suyanaycu \\ Esperanza de nosotros pecadores}

\section{Maypis mama yahuar hueqque}

¿Dónde, madre, [hay] lágrimas de sangre

\section{Ccanhuan cusca huaccanaipacc \\ Para llorar junto a ti?}

Los himnos Tipo 2 se distinguen claramente de las composiciones de Oré y Pérez Bocanegra, que utilizaban patrones métricos más complejos. Estos himnos carecen además del juego deliberadamente "sincrético" de iconografía cristiana con imágenes y temas derivados del pensamiento ritual y cosmológico andino que destaca en los himnos Tipo 1. Por ejemplo, los himnos a la Virgen utilizan la iconografía mariana tradicional de origen europeo (flores, la luna, las estrellas, etc.) sin la clase de sustitutos andinos ensayados por Oré y Pérez Bocanegra más allá del ubicuo hamancay (flor de amancae).

Estos contrastes no escaparon a la atención de Arguedas. Aunque no conocía el origen de la versión del Capac eterno Dios proporcionada por Lira, notó que era diferente de los demás himnos. Lo destaca por su carácter "discursivo", "lógico", y "casi triunfal", oponiéndolo a los demás himnos, cuyo objetivo era infundir "el terror por la muerte y el pecado" (Arguedas 1955:134). Lo contrasta en particular con el ya mencionado himno eucarístico Mesan mast'asqa, que figura tanto en los Tesoros Religiosos (Anónimo 1834:57-58) como en el devocionario de Mariano Guzmán (1843:53-54). Este último lo identifica como unas "endechas al santísimo sacramento, en metáfora de un pobre que pide limosna: para resar antes de la Santa Comunión". Citaré dos estrofas de este himno:

$\begin{array}{ll}\begin{array}{l}\text { Yarccallahuanmi, } \\ \text { Ucuyquimanta, } \\ \text { chaqquillahuanmi, } \\ \text { unuyquimanta. }\end{array} & \begin{array}{l}\text { Tengo hambre } \\ \text { de tu cuerpo, } \\ \text { tengo sed } \\ \text { de tu agua. }\end{array} \\ \begin{array}{l}\text { Ucullayquita, } \\ \text { micuchillahuay, } \\ \text { Yahuarñiquita } \\ \text { ucyachillahuay }\end{array} & \begin{array}{l}\text { Tu cuerpo } \\ \text { hazme comer, } \\ \text { tu sangre } \\ \text { hazme beber }\end{array}\end{array}$

Para Arguedas este himno expresaba un "insondable y complejo estado de necesidad, de angustia física e interior", pero también lo destaca por su "estructura formal autóctona", la cual le lleva a afirmar que este himno "no pudo haber sido escrito por un misionero recién convertido al quechua, sino por algún quechua sólidamente convertido al catolicismo" (Arguedas 1955:136, 137). Al igual que los himnos Tipo 1, el Mesan mast'asqa se caracteriza por una composición basada en el paralelismo semántico-sintáctico combinado con el esquema métrico. Sin embargo, se diferencia claramente de ellos por su gran economía formal, por el carácter extremadamente íntimo y directo del discurso, y por la ausencia de contenido explícitamente catequístico. Compárese la siguiente estrofa de la versión original del Qanmi Dios kanki de Oré (1992 [1598]:324):

\section{Chunca hostiapas huarancapas captin, \\ Aunque sean cien hostias, o mil,}

manam Diosñinchic raquircayacunchu: nuestro Dios no se divide,

huc çapallanmi llapantimpi tian
uno solo está en todas ellas juntas:

checan Dios Christo.

Cristo, el Dios verdadero.

El Mesan mast'asqa no afirma ni explica el dogma de la Eucaristía, simplemente es una imploración dirigida a Cristo en el sacramento de la misa.

El repertorio actual corresponde principalmente al Tipo 2, de manera que es especialmente importante comprender su desarrollo histórico. 
Todo indica que los himnos que aparecen en los Tesoros Religiosos y el devocionario de Mariano Guzmán ya formaban parte de un repertorio establecido. No se les atribuye autor alguno, ni se les distingue como textos de origen reciente. Como ya se mencionó, un himno Tipo 2 aparece en un manuscrito ayacuchano que parece datar de fines del siglo XVIII. Sugiero entonces que el Tipo 2 corresponde a un desarrollo dieciochesco, lo que no impide que himnos de este tipo hayan seguido componiéndose en los siglos XIX y XX.

Las melodías de estos himnos pueden entregar claves importantes sobre sus orígenes. Según Pilco Paz, en el repertorio actual predomina un estilo musical que incorpora elementos del yaraví y del huayno, géneros profanos mestizos que se estaban consolidando y popularizando justamente en el siglo XVIII (Pilco Paz 2005:181, 195-197). Especifica que "la forma [musical] del yaraví es característica de los himnos a Cristo y a la Virgen Dolorosa, así como los de la liturgia" (Pilco Paz 2005:196). Esta observación encaja con una propuesta de Geoffrey Baker, que ve una especie de revolución en la música religiosa cuzqueña hacia fines del siglo XVIII. A medida que se daba un declive en la actividad musical en la ciudad del Cusco, las parroquias rurales con sus músicos indígenas se convirtieron en centros musicales dinámicos y relativamente autónomos. Gracias a estas circunstancias se habría llevado a cabo una fusión de música sacra y profana, europea y andina dentro de un contexto que podría denominarse popular (Baker 2003:199-201).

Parece bastante plausible que el desarrollo del himno quechua Tipo 2 formara parte de este proceso musical y social. Mientras que los himnos Tipo 2 parecen sencillos y ortodoxos en su contenido e iconografía, musicalmente debieron constituir una innovación radical en su momento. Según Baker la reacción inicial de las autoridades coloniales a los cambios en la música religiosa en las parroquias indígenas fue hostil: no era aceptable que, por ejemplo, una melodía de yaraví se escuchara en la misa (Baker 2002:200). Sin embargo, este nuevo tipo de música religiosa, y los textos asociados con él, terminaron imponiéndose gracias a su popularidad y probablemente también a cambios que se dieron dentro de la iglesia con la independencia. Hacia mediados del siglo XIX ya habrían alcanzado el reconocimiento del clero, de manera que se les incorporó a los nuevos impresos pastorales.

\section{El Siglo XX y el Indigenismo Eclesiástico}

Durante las primeras décadas del siglo XX se desarrolló una nueva etapa en la producción y difusión de himnos quechuas cuyo contexto histórico se conoce mucho mejor. Por primera vez desde mediados del siglo XVII encontramos sacerdotes que componían textos nuevos y se dedicaban al "cultivo" del quechua por medio de estudios lingüísticos. Estos esfuerzos formaron parte de un boom quechuístico más amplio asociado con el auge del indigenismo cusqueño. El indigenismo de la época buscaba forjar un espíritu nacional y regional a través de la resucitación de una herencia incaica, pero era a la vez una ideología netamente elitista según la cual los "indígenas", o campesinos quechua-hablantes actuales, habían caído en un estado de degeneración moral y intelectual del cual debían ser rescatados. Como han mostrado los estudios de César Itier, una de las expresiones claves del indigenismo cusqueño fue el proyecto de restaurar y difundir un supuesto quechua incaico, particularmente a través de obras teatrales en quechua ambientadas en el incanato que alcanzaron su auge entre 1914 y 1922. Este proyecto lingüístico involucraba la recuperación de un vocabulario quechua perdido que se entendía como la expresión del alto nivel intelectual de las elites incaicas, y la eliminación dentro de lo posible de los préstamos del castellano (Itier 1995, 2000).

Algunos de los representantes claves del indigenismo cusqueño fueron sacerdotes, y se podría hablar de una variante eclesiástica del indigenismo. Se estaba dando por estos años un nuevo boom misionero, reflejado en una extensa literatura pastoral en quechua publicada en Cusco y otras ciudades peruanas. Los sectores indigenistas del clero percibían una continuidad o simpatía esencial entre lo incaico y lo cristiano, de manera que no había contradicción alguna entre el incaísmo y la tarea de re-evangelizar a los "indígenas". Una parte de la nueva literatura pastoral refleja un afán por "incaizar" al campesinado a través de un nuevo lenguaje cristiano en quechua que seguía las pautas del indigenismo laico.

La figura más destacada de esta camada de sacerdotes quechuistas fue el franciscano cusqueño José Gregorio Castro, obispo del Cusco entre 1910 y 1917. Además de publicar compilaciones de textos pastorales en quechua, escribió una gramática, un diccionario, y una "ortología" o guía ortográfica 
quechua (Rivet y Créqui-Montfort 1951-1956, II:458-460). El principal autor de dramas incaicos de la época, Nemesio Zúñiga Cazorla (nacido en Calca 1895), no estuvo ajeno a esta renovación de la literatura pastoral -había sido apadrinado por José Gregorio Castro debido a sus dotes como quechuista y fue uno de los predicadores más famosos de la época, participando activamente en novenas y misiones durante los años treinta (Itier 1995:19-20, 23). Al parecer también se destacó como compositor de himnos; se le atribuye uno de los himnos más importantes de la actualidad, el Qosqo llaqta (Ricardo Castro Pinto, comunicación personal, 2002).

En 1920 Castro publicó un devocionario con el decidor título Florilegio incaico que contiene una variedad de oraciones, sermones e himnos "para el tiempo de las santas misiones," algunos tradicionales y otros compuestos por él. Los himnos de Castro reflejan un esfuerzo por desarrollar un lenguaje "elevado" típico del indigenismo de la época, lo que involucraba la recuperación de un vocabulario religioso presuntamente incaico. Para esto se valió de los textos de Pérez Bocanegra, autor que en su época se destacó por el uso de términos asociados con las instituciones religiosas incaicas. Por ejemplo, Castro tomó de Pérez Bocanegra el uso de los términos incaicos aclla (ajlla) y raymi para "monja" y "fiesta religiosa" respectivamente (Castro 1920:162, 177; cf. Durston 2007:218-219). Pretendía remplazar así los préstamos castellanos que se habían establecido en el léxico cristiano desde los tiempos del III Concilio Limense. No hay mayores indicios sobre la clase de música favorecida por Castro ni se sabe si componía melodías para sus himnos. No he podido identificar obras suyas en el repertorio actual, pero el Qosqo llaqta, atribuido a Zúñiga Cazorla, sí se interpreta y aparece en muchas de la compilaciones más recientes de himnos quechuas (p.ej., Manya 1972:158). Como texto verbal, por lo menos, el Qosqo llaqta es en el fondo un himno al Cusco, lleno de referencias incaicas.

Finalmente cabe mencionar un personaje más reciente que ya ha figurado en este artículo, el padre Jorge A. Lira. A pesar del carácter documentalista e incluso etnográfico de su trabajo, Lira compartía muchas de las tendencias incaistas de la generación anterior de indigenistas cusqueños. El objetivo declarado del Lira era documentar y conservar elementos de la cultura campesina, como era frecuente en los indigenistas de mediados del siglo XX, pero a la vez realizaba importantes modificaciones al léxico de los himnos que transcribía y publicaba, remplazando préstamos religiosos del castellano con presuntos equivalentes incaicos, algunos de los cuales parece haber inventado él mismo ${ }^{10}$. $\mathrm{Al}$ igual que los sacerdotes quechuistas que le precedieron, Lira entendía su tarea como la de restaurar un lenguaje religioso perdido. Consideraba incluso que algunos de los himnos que recogió eran "rectificaciones de las mismas estrofas que se cantaban en los recintos sagrados del inkanato" (Lira 1955:167). Los himnos incaicos tuvieron que ser "rectificados" después de la conquista porque los incas no habían tenido conocimiento directo y explícito de la historia sagrada (por ejemplo, no podían llamar a Cristo o a la Virgen María por sus nombres). Sin embargo, las rectificaciones fueron demasiado lejos al introducir préstamos castellanos para nombrar conceptos cristianos que los incas sí habían manejado. En el fondo, era la cultura de los quechua-hablantes del siglo XX la que debía ser "rectificada" para devolverla a sus raíces incaicas.

\section{Conclusiones}

Suele pensarse que los himnos quechuas que se cantan en las misas y fiestas cuzqueñas son muy antiguos, es decir, que datan de los primeros tiempos de la evangelización o incluso que son adaptaciones de supuestos himnos incaicos. Como ocurre con casi todo lo que tiene que ver con el quechua, hay una tendencia a buscar lo antiguo y lo puro. Queda claro, sin embargo, que el repertorio actual incluye himnos de distintos estilos verbales y musicales, los que a su vez están asociados a contextos y proyectos sociales que se dieron en momentos históricos muy diversos, algunos de ellos relativamente recientes.

Se recuerda muy poco del primer repertorio evangelizador, o Tipo 1 , los himnos compuestos por sacerdotes quechuistas como Oré y Pérez Bocanegra hacia fines del siglo XVI y comienzos del XVII. En cambio, hay un predominio amplio de lo que he denominado el Tipo 2, que se habría desarrollado en sectores populares durante el siglo XVIII. Recién comienza a aparecer en la literatura impresa a partir de la década de 1830 gracias a la liberalización de la imprenta después de la independencia. Los textos de estos himnos, de escaso contenido doctrinal, son instrumentos de catarsis emocional para las fiestas y los momentos más importantes de la liturgia. Su popularidad se debe también (y quizás 
en mayor medida) a sus melodías, que incorporan elementos musicales profanos y populares de una manera que inicialmente causó bastante recelo entre el clero. Un tercer momento de creación se puede identificar a partir de comienzos del siglo XX, tiempo de efervescencia cuando aparecen himnos nuevos influenciados por el indigenismo. Se trata ahora de un movimiento dirigido por una elite que buscaba elaborar un lenguaje religioso más elevado y más fiel a las raíces históricas de la región. Estos esfuerzos tuvieron resultados muy limitados, en todo caso, el impulso de renovación léxica no ha dejado mayores huellas en el lenguaje de la oración y el canto litúrgico quechua.

Para terminar, solo mencionaré algunos de los desarrollos más recientes en la historia del himno quechua en el Cusco cuyas implicaciones podrían explorarse en estudios futuros. Un nuevo tipo de himno ha surgido de la búsqueda por parte de algunos sectores del clero de formas litúrgicas y catequísticas que permitan un mayor protagonismo para, y una reivindicación cultural de, el campesinado andino. Estos himnos están claramente asociados con la teología de la liberación y los esfuerzos por una "inculturación" de la fe cristiana con el contexto andino. Evitan el discurso de culpa y arrepentimiento que predomina en los himnos tradicionales (sobre todo en los del Tipo 2). Se caracterizan también por una música más vivaz y alegre y por el uso de instrumentos que hasta ahora han sido excluidos de la música sacra, como la guitarra y la armónica. En esto muestran una marcada influencia de los movimientos evangélicos, los que han estado desarrollando su propio estilo de canto religioso en quechua desde hace algún tiempo ${ }^{11}$.

Agradecimientos: Este estudio se basa en trabajo de campo y archivo, realizado en 2002, gracias a una beca para estudios doctorales de la WennerGren Foundation for Anthropological Research. Agradezco también la ayuda y la orientación de varios cusqueños, en especial Ricardo Castro Pinto, Carmen Escalante y Ricardo Valderrama, durante mi trabajo de campo en Cusco, y los comentarios a una primera versión del trabajo proporcionados por César Iter.

\section{Referencias Citadas}

Andía, N.

1950 Catecismo y Devocionario en Quechua. H.G. Rozas, Cusco.

Anónimo

s.f. Devocionario quechua sin título en la biblioteca del convento de San Francisco, Ayacucho.

Anónimo

1834 Tesoros Religiosos en Castellano y Quichua. Cusco.

Arguedas, J.M.

1955 Los himnos quechuas católicos cuzqueños. Colección del padre Jorge A. Lira y de J.M B. Farfán. Folklore Americano $3(3): 121-232$.

Baker, G.

2003 La vida musical de las doctrinas de indios del obispado del Cusco. Revista Andina 37:181-205.

Castro, J.G.

1920 Florilegio Incaico. Sanmartí y Cía., Lima.

Durston, A.

2007 Pastoral Quechua: The History of Christian Translation in Colonial Peru, 1550-1650. University of Notre Dame Press, Notre Dame.

Estenssoro Fuchs, J.C.

1992 Los bailes y el proyecto colonial. Revista Andina 10/2:353-389

2003 Del Paganismo a la Santidad. La Incorporación de los Indios del Perú al Catolicismo, 1532-1750. Instituto Francés de Estudios Andinos y Pontificia Universidad Católica del Perú, Lima.

González Holguín, D.

1989 [1607] Vocabulario de la lengua general de todo el Perú llamada lengua qquichua o del Inca. Universidad Nacional Mayor de San Marcos, Lima.
Guzmán, M.

1843 Catecismo y Doctrina Cristiana en el Idioma Qquechua. Cusco.

Itier, C.

1995 El Teatro Quechua en el Cuzco. Tomo I. Dramas y Comedias de Nemesio Zúñiga Cazorla. Institut Français d'Études Andines y Centro de Estudios Regionales Andinos "Bartolomé de Las Casas", Lima.

2000 El Teatro Quechua en el Cuzco. Tomo II. Indigenismo, Lengua y Literatura en el Perú Moderno. Institut Français d'Études Andines y Centro de Estudios Regionales Andinos "Bartolomé de Las Casas", Lima.

Lira, J.A.

1944 Diccionario Kkechuwa-Español. Universidad Nacional de Tucumán, Tucumán.

1955 Recopilación del Padre Jorge A. Lira. Himnos a Dios y a Jesucristo. En Arguedas 1955: 167-221.

1988 Himnos Quechuas. Lima.

Mannheim, B.

1986 Poetic form in Guaman Poma's wariqsa arawi. Amerindia 11:41-67.

1999 El arado del tiempo: poética quechua y formación nacional. Revista Andina 17 (1):15-64.

Murra, J.V.

1978 Introduction. En José María Arguedas Deep Rivers (traducción de Frances Horning Barraclough), p. ix-xv. Waveland Press, Prospect Heights.

Oré, L.J. de

1992 [1598] Symbolo Catholico Indiano (edición facsimilar a cargo de Antonine Tibesar). Australis, Lima. 
Pérez Bocanegra, J.

1631 Ritual Formulario, e Institucion de Curas, para Administrar a los Naturales de Este Reyno, los Santos Sacramentos. Jerónimo de Contreras, Lima.

Pilco Paz, E.

2002 La musique d'église dans les Andes. De la polyphonie au yaraví dans le cathédrale de Cuzco (XVIéme-XIXéme siècle). Memoire DEA d'Anthropologie sociale et Ethnologie, Ecoles des Hautes Etudes en Sciences Sociales.

2005 Maestros de capilla, mestizaje musical y catolicismo en los andes del sur. Revista Andina 40:179-208.

Porccheda Diana, F.

1986 Dios Taytanchista Yupaychasun. Sicuani.

Prado, P. de

1641 Directorio Espiritual en la Lengua Española y Quichua General del Inga. Jorge López de Herrera, Lima.
Prado, P. de y G. Manuel

1705 Selectas de el Directorio Espiritual. Imprenta Real, Lima.

Quispe, H. y J.M. García

1986 Diospa Llaqtanpi Huñukusunchis. Cusco.

Rivet, P. y G. de Créqui-Montfort

1951-1956 Bibliographie des Langues Aymará et Kićua (4 tomos). Institut d'Ethnologie, Paris.

Tercer Concilio Limense

1985 [1584, 1585] Doctrina christiana y catecismo para instruccion de indios. Facsímil del texto trilingüe (edición facsimilar de los tres volúmenes trilingües a cargo de Luciano Pereña). Consejo Superior de Investigaciones Científicas, Madrid.

Vicente, J. de D.

1963 Hanacpacha Puncu. Cusco.

\section{Notas}

1 El término "himno" se puede utilizar con varios sentidos, algunos más amplios y otros más especializados. En el sentido amplio un himno es una canción de culto religioso de composición estrófica, de manera que hay una relación estrecha entre las unidades verbales (versos y estrofas) y la melodía.

2 Comunicaciones personales de Frank Salomon y Calogero Santoro, 2008.

3 Por cierto, el Cusco no es el único punto de la sierra peruana (por no mencionar a Bolivia y Ecuador) donde se cantan himnos quechuas, de hecho sería interesante realizar un cotejo de los repertorios de distinas zonas quechua-hablantes, como ya indicó Arguedas (1955:121-122).

4 Para escribir los títulos de los himnos quechuas vigentes usaré la ortografía oficial moderna del quechua cusqueño, pero al referirme a himnos que sólo he encontrado en libros usaré la ortografía empleada en el texto.

5 Como medida para frenar este proceso de pérdida Ricardo Castro Pinto, maestro de capilla de la catedral, está formando una recopilación de himnos con partituras que espera publicar como libro (comunicación personal, 2002).

6 Una excepción importante es la reedicion de 1705 del devocionario de Prado que contiene un himno nuevo narrando la pasión de Cristo (Prado y Manuel 1705).

7 Agradezco a Xavier Pello por darme acceso a una fotocopia de este manuscrito, que descubrió en la biblioteca del convento franciscano de Ayacucho.
8 En el ejemplar de la colección Rivet, conservado en la Biblioteca Nacional del Perú, la fecha de imprenta ha sido parcialmente borrada. La fecha 1834 es sugerida por Rivet y Créqui-Montfort (1951-1956:I 310).

9 Sigo la traducción de Arguedas (1955:135-136), excepto que traduzco uси como "cuerpo", no "ser".

10 En la colección de himnos que apareció con el artículo de Arguedas y en una publicación posterior Lira sistemáticamente remplazaba los prestamos alma o ánima con nuna, santo o santa con willkay, virgen con ahlla, y ángel con yakill, entre otros cambios léxicos. Nuna es de uso muy raro, pero tiene precedentes (González Holguín 1989 [1607]:263), mientras que ahlla (aclla) se habia usado para "monja", aunque no para "virgen". Willkay y yakill parecen ser primicias de Lira (willkay deriva de willka, antiguo sinónimo de "huaca", y yakill supuestamente significa "mensajero", de manera que la acepción "ángel" se remite a la etimología griega de la palabra). Todos estos neologismos religiosos se encuentran debidamente explicados y ejemplificados en el diccionario de Lira (1944), que estaba dedicado (en quechua) a la gloria de Dios y de la Virgen (Lira 1944:1200). Estos cambios son especialmente evidentes en los himnos marianos Napaykuykin kkocha kkoyllur (Lira 1988:106) y Llakiymanaskka ahlla (ibid: 196), cuyas versiones tradicionales se pueden encontrar en Andía 1950 (pp. 226 y 219-221) y en varios otros devocionarios de los siglos XIX y XX.

11 Baso estos comentarios finales principalmente en mis observaciones en la parroquia jesuita de Urcos en el 2002. 
